\title{
PENGEMBANGAN MODUL BAHAN AJAR SEJARAH BERBASIS PERJUANGAN MASYARAKAT TENGARAN SELAMA REVOLUSI FISIK UNTUK MENINGKATKAN NASIONALISME
}

\section{DEVELOPMENT OF HISTORY LEARNING MATERIAL MODULE BASED ON TENGARAN SOCIETY OF SEMARANG REGENCY'S STRUGGLE DURING PHYSICAL REVOLUTION TO IMPROVE NATIONALISM}

\author{
Dimas Anggoro', Wasino², ${ }^{1}$,ariyatun ${ }^{3}$ \\ ${ }^{1,2,3}$ Program Magister Pendidikan Sejarah Pasca Sarjana Universitas Sebelas Maret Surakarta
}

\begin{abstract}
Abstrak : Bahan ajar sejarah lokal yang berhasil dikembangkan adalah sebuah modul berjudul "Sejarah Perjuangan Masyarakat Tengaran selama Revolusi Fisik 1947-1949". Desain pengembangan modul menggunakan model ADDIE yang meliputi lima langkah : analisis kebutuhan, desain produk, pengembangan, implementasi, dan evaluasi. Pakar pembelajaran dari Universitas Sebelas Maret Surakarta dan guru mata pelajaran sejarah Indonesia dari SMA Negeri 1 Tengaran memberi nilai terhadap modul pada aspek media sebesar 51 atau 92,72\% (sangat baik) dan aspek materi sebesar 46,5 atau 93\% (sangat baik). Modul diujicobakan kepada 35 siswa terbukti dapat dibelajarkan sebagai materi sejarah Indonesia pada pembahasan tentang Revolusi Nasional Indonesia. Uji efektifitas modul terhadap peningkatan nasionalisme menggunakan desain penelitian kuasi eksperimen melalui uji pretest dan posttest pada dua kelompok berbeda (kelompok eksperimental dan kontrol). Hasil uji beda (independent sample $t$ test) menunjukan adanya perbedaan efek penggunaan bahan ajar terhadap peningkatan nasionalisme siswa mencapai $25,17 \%$ dengan nilai probabilitas $=0,00$ lebih kecil daripada alpha $=0,05$. Modul terbukti memberi pengaruh lebih besar terhadap peningkatan nasionalisme siswa dibanding bahan ajar konvensional (handout) dengan skor rerata posttest nasionalisme kelas eksperimen sebesar 85,53 (sangat baik) sedangkan kelas kontrol 77,00 (baik).
\end{abstract}

Kata Kunci: Bahan Ajar, Modul, Sejarah Lokal, Nasionalisme Siswa

\begin{abstract}
The Local History learning material developed was a module entitled "Sejarah Perjuangan Masyarakat Tengaran selama Revolusi Fisik 1947 - 1949" (Tengaran Society's Stuggle History during the Physical Revolution of 1947 - 1949). The development design used the ADDIE model which consisted of five stages, namely: need analysis, product design, development, implementation, and evaluation. The product assessment was done by two experts from Sebelas Maret University and two History teachers of State Senior Secondary School I of Tengaran. They gave score 51 (92.72\%) or very good category on the media aspect and 46.5 (93\%) or very good category on the learning material aspect. The developed module tested to 35 students is proven to be feasible to be instructed as Indonesian history learning material on the topic of discussion Indonesia's National Revolution. The effectiveness testing of the developed module on the nationalism improvement used the quasi experimental research with the pre-test and post-test design to two different groups of students (experimental group and control group). The independent sample t test shows that there is a different effect of the learning material use on the students nationalism improvement as much as $25 \%$ with the probability value $=0.000$ which was less than alpha $=0.05$. The developed module is proven to have a greater effect on the students nationalism improvement than the conventional one (handout) as indicated by the results of the post-test in which the average score of the experimental group was 85.53 (very good) whereas that of the control group was 77,00 (good).
\end{abstract}

Keywords: Learning material, module, local history, students nationalism 


\section{PENDAHULUAN}

Pemberlakuan kurikulum 2013 di sekolah menengah atas (SMA) bertujuan untuk membentuk mentalitas manusia Indonesia yang cerdas secara spiritual, emosi, sosial, dan kognitif. Pentingnya mata pelajaran sejarah Indonesia dibelajarkan pada kurikulum ini bagi keberlangsungan bangsa Indonesia ke depan sebenarnya ada pada arti strategis pembangunan moral bangsa yaitu membentuk watak dan peradaban bangsa Indonesia yang mencintai tanah airnya sendiri (Kemendikbud, 2014: 2-3). Sejalan dengan pembangunan moral kebangsaan, nasionalisme merupakan paham bagi seseorang maupun kelompok masyarakat yang mencitacitakan suatu kehidupan berbangsa dan bertanah air bersama. Basis filosofi nasionalisme ini digunakan oleh suatu negara sebagai sumber kekuatan untuk melindungi keberadaannya. Kekuatan tersebut berasal dari kerelaan warga negaranya untuk membela tanah airnya (Blank dan Schmidt 2003 dalam Latcheva, 2010:192). Timbulnya kerelaan tersebut didasari oleh adanya ikatan kekeluargaan disertai dengan penghormatan terhadap nilai-nilai yang dijunjung bersama. Nilai-nilai tersebut dimanifestasikan ke dalam kehidupan berbangsa seperti pada pemakaian bahasa, beragama, dan kerjasama ekonomi yang membuat mereka tetap utuh untuk hidup bersama (Jhonson, 1966 dalam Rocher, 2002: 4).

Nasionalisme suatu bangsa selalu terikat pada akar kebudayaan tempat bangsa itu hidup (Naoko Hosokawa dalam Vorokova dan Mansour, 2015: 3). Adanya peran budaya ditujukan untuk membangkitkan kembali komunitas moral bangsa yang dibangun di atas kerangka keberagam etnik, linguistik, religius, dan subkultural berdasarkan prinsip kesatuan (Kartodirdjo, 1993:15). Perkembangan jaman akan membawa perubahan paradigma tentang nasionalisme. Nasionalisme yang dirajut di jaman pra-kemerdekaan mungkin sudah tidak relevan lagi diterapkan sekarang ini. Meskipun demikian, nasionalisme masih tetap dapat terbentuk apabila terdapat prinsip-prinsip seperti kesatuan (unity), kebebasan (liberty), kesamaan (equality), kepribadian (personality), dan prestasi (performance) dalam suatu bangsa (Kartodirdjo, 2003, 15).

Pembelajaran sejarah Indonesia akan bermakna apabila dalam pembelajarannya guru dapat menyalurkan nilai-nilai kepahlawanan dan mempertahankan tatanan yang berlaku dalam masyarakat (Cardona 1993 dalam Fernández, 2013:34). Tatanan (order) yang dimaksud adalah tatanan sosial yang sesuai dengan kebudayaan bangsa Indonesia. Materi pembelajaran sejarah Indonesia bersumber dari sejarah nasional yaitu sejarah tentang proses integrasi politik yang membentuk sebuah negara nasional bernama Republik Indonesia (Suhartono, 2010: 90). Cakupan sumber materi sejarah Indonesia sangat luas meliputi semua periode sejarah 
Indonesia, dimana sumber tersebut dapat berupa peristiwa atau tokoh tingkat nasional maupun daerah yang keduanya memiliki kedudukan yang sama penting dalam perjalanan sejarah Indonesia (Kemendikbud, 2014: 2). Sebagai bagian dari SNI, sejarah lokal syarat dengan identitas kelokalan yang menjadi akar identitas nasional. Hal tersebut bisa terjadi karena adanya transaksi budaya lokal dimana dinamika antarbudaya akan melahirkan suatu proses perkembangan dari identitas, solidaritas, dan kebanggaan lokal menuju identitas, solidaritas dan kebanggan nasional (Priyadi 2014: 40-41). Adanya peran sejarah lokal dalam pembentukan identitas nasional berfungsi sebagai penegas kepribadian siswa sebagai bagian dari suatu masyarakat yang terbentuk melalui ikatan sosial di masa lalunya (Pagès dan Monfort, 2010 dalam Fernández, 2013: 39). Pada tujuannya mempertahankan kepribadian lokal bukan berarti memupuk etnosentrisme pada diri siswa tetapi dalam rangka memperkuat jati diri bangsa Indonesia sebagai bangsa yang berbhinneka tunggal ika (Fernández, 2013: 39). Implementasi pembelajaran sejarah dengan konteks lokal merujuk pada UU No. 20 Tahun 2003 BAB XIV pasal 50 ayat 5 tentang keunggulan lokal dimana sejarah lokal termasuk keunggulan daerah, sehingga Pemerintah Kabupaten/ Kota memperbolehkan sejarah lokal dibelajarkan di sekolahsekolah dari tingkat dasar hingga menengah. Kemudian sebagai penguatnya adalah PP No. 19 Tahun 2005 BAB III pasal 14 ayat 1 yang menyatakan bahwa SMA/MA/SMALB atau yang sederajat diperbolehkan memasukan pendidikan berbasis keunggulan lokal sebagai bahan ajar. Dari dasar itulah, bahan ajar sejarah lokal perjuangan masyarakat Tengaran selama Revolusi Fisik 1947-1949 ini dikembangkan di SMA N 1 Tengaran.

Proses pembelajaran merupakan proses komunikasi yang diwujudkan melalui penyampaian informasi dari guru ke siswa. Informasi tersebut dapat berupa pengetahuan, keahlian, skill, ide, pengalaman, dan sebagainya. Guru biasanya mengemas informasi tersebut ke dalam sebuah kesatuan yang dinamakan bahan ajar (teaching material) (Daryanto dan Cahyono, 2014: 190). Bahan ajar sebagai seperangkat materi pelajaran disusun secara sistematis berdasarkan urutan kompetensi belajar siswa (Dick dan Carey 1985:170). Penggunaan bahan ajar oleh guru ditujukan untuk menghasilkan efektifitas dan efisiensi dalam pembelajaran. Oleh karena itu untuk memaksimalkan hasil pembelajarannya penggunaan bahan ajar harus disesuaikan dengan kebutuhan siswa (Sekyere, 2002 dalam Fentim, 2014: 84)

Proses belajar mengajar merupakan suatu sistem dimana di dalamnya terdapat komponen yang saling terintegrasi untuk mencapai tujuan belajar siswa. Penggunaan bahan ajar yang kurang memumpuni akan memberi pengaruh negatif pada pencapaian belajar mereka (Hosnan, 2014: 111). Modul merupakan paket program yang disusun dalam bentuk cetak untuk 
keperluan belajar (Wijaya 1992 dalam Daryanto dan Aris, 2014: 177). Pada fungsinya modul digunakan sebagai suplemen untuk meningkatkan prestasi belajar siswa, oleh karena itu modul harus memiliki rangkaian kegiatan belajar yang jelas (Macarandang, 2009:1). Kelebihan penggunaan modul yaitu dapat dipelajari siswa sesuai kemampuan belajarnya sendiri-sendiri (Dizon, 1998 dalam Naval 2014: 146). Hal itu karena modul telah dibekali dengan langkahlangkah pengoperasian yang dapat diikuti oleh siswa. Namun pada kondisi tertentu seperti untuk memaksimalkan proses pembelajaran di kelas modul dapat dibelajarkan secara berkelompok (Larawan, 2013: 13).

\section{METODE}

Penelitian ini menerapkan metode Research and Development (R\&D) yaitu suatu metode penelitian untuk menghasilkan produk sekaligus menguji keefektifannya (Sugiyono, 2013:407). Produk yang dikembangkan berupa bahan ajar modul sejarah lokal berjudul perjuangan masyarakat Tengaran selama Revolusi Fisik 1947-1949. Subjek penelitian adalah siswa SMA N 1 Tengaran kelas XI Semester 1 Tahun ajaran 2015/2016 berjumlah 99 siswa dengan perincian: kelompok uji coba skala kecil sebanyak 4 siswa, kelompok uji coba skala luas sebanyak 31 siswa, kelompok eksperimen sebanyak 32 siswa, dan kelompok kontrol sebanyak 32 siswa. Validator modul terdiri dari empat ahli pembelajaran dengan perincian dua ahli media dan dua ahli materi. Penelitian ini dilakukan melalui tiga tahap yaitu: studi pendahuluan, pengembangan produk, dan evaluasi (Sukmadinata, 2007: 184-187). Desain penelitan pengembangan produk menggunakan model ADDIE yang berisi lima langkah, 1) analysis, 2) design, 3) development, 4) implementation, dan 5 evaluation Pribadi, 2014: 179). Sedangkan untuk uji efektifitas produk menggunakan desain penelitian kuasi-eksperimental.

\section{HASIL DAN PEMBAHASAN}

\section{Desain Modul}

Penulisan sejarah sebagai ide cerita edukasi menjembatani siswa untuk mengetahui rangkaian peristiwa masa kini dengan masa lalu lingkungannya. Melalui bacaan yang tersaji dalam materi guru sejarah dapat menyusun dasar-dasar kejiwaan siswa. Pembelokan gerak alam sadar siswa dapat dilakukan dengan mengenalkan dan memancing keingintahuan siswa pada kejadian-kejadian disekitarnya yang kemudian pengetahuan itu dikaitkan dengan tujuan program yang dibuat guru. Dari cerita sejarah siswa akan memperoleh informasi berupa fakta yang berguna untuk pengembangan moral mereka, sehingga melalui penyajian materi yang 
edukatif dan bermakna akan membelajarkan siswa untuk menjadi pribadi yang dewasa baik pikiran dan emosi (Shelley, 1990 dalam Bage, 2002:38).

Konsep kepahlawan selama ini masih berlaku dan menjadi topik identitas kebangsaan. Modul sejarah lokal yang dikembangkan harus mampu memerankan peranannya dalam pembentukan nasionalisme dalam diri siswa maka pada penyampaian materinya lebih diutamakan pada transfer nilai-nilai nasionalisme yang disisipkan melalui cerita aksi-aksi heroik pejuang lokal Tengaran dahulu. Pelibatan tokoh militer dan politik menjadi simbol untuk penyebaran semangat kebangsaan. Hal itu karena figur tokoh memiliki karakter khas yang menjadi sumber inspirasi dan mampu mempengaruhi karakter siswa (Tsyrlina, Spady dan Lovorn, 2015: 169).

Pengembangan materi ajar sejarah lokal sebagai materi ajar sejarah nasional didasarkan pada dua pengintegrasian yaitu sumber sejarah dan kompetensi pembelajaran. Pengintergrasian sumber sejarah lokal dan sejarah nasional didasarkan atas kecenderungan kesamaan pola, dan struktur peristiwa yang dimiliki antara sejarah lokal dan nasional sebagai bagian dari unit mikro dengan unit makro sejarah ataupun sebaliknya. Sedangkan pengintegrasian sumber materi ajar dengan kompetensi belajar siswa didasarkan pada amanat PP No. 19 Tahun 2005 tentang Standar Nasional Pendidikan tentang kompetensi lulusan (Rusman, 2014: 4). Pada kurikulum 2013 kompetensi lulusan dibakukan menjadi spesifikasi dari pengetahuan, keterampilan, dan sikap serta penerapan dari pengetahuan dan keterampilan yang memuat persyaratan minimal yang harus dimiliki siswa yaitu Kompetensi Inti (KI) dan Kompetensi Dasar (KD) (Hosnan, 2014: 23).

Meskipun media cetak sudah ketinggalan jaman namun media ini memiliki keuntungan dalam penggunaannya yaitu lebih ramah kepada mata pembaca. Hal itu karena penggunaan kertas tidak menyilaukan dibandingkan dengan penggunakan e-book. Begitupula membaca alur teks di dalamnya, apabila pembaca belum memahami isi materi mereka dapat dengan mudah membolak-balik halaman (Tanner, 2014: 9).

Teknologi pembelajaran berbasis media interaktif perlu dimasukan dalam modul karena pengaruhnya banyak membantu siswa dalam meningkatkan prestasinya. Modul sedianya disusun interaktif agar siswa mudah mempelajari materi di dalamnya. Modul interaktif membantu siswa mengenali lingkungannya dan berpengaruh pada peningkatan motivasi belajar siswa. Martin, dkk., (2013) menggunakan story board dalam modulnya berhasil mengenalkan bangunan cagar budaya di Kota Wilmington Amerika Serikat kepada siswa. Modul yang disusun interaktif ini terbukti dapat meningkatkan kebutuhan siswa mempelajari 
situs bersejarah di lingkungan kota tersebut dengan mengajak siswa berkunjung ke situs secara virtual (Martin, dkk., 2013: 16). Melalui dialog interaktif dan pengenalan norma di dalamnya tentu akan memudahkan siswa memahami materi (Faiella, 2013: 40).

\section{Pengembangan Modul}

Tujuan pengembangan modul adalah mengetahui kelayakannya baik dari sisi aspek media maupun materinya sebagai bahan ajar Sejarah Indonesia kelas XI menurut penilaian tim ahli. Pengkategorian kelayakan modul mengikuti skala penilaian sebagai berikut:

\begin{tabular}{ccc}
\hline Kategori & Skala & Persentase \\
\hline Sangat Baik & 5 & $100 \%$ \\
\hline Baik & 4 & $<80 \%$ \\
\hline Cukup & 3 & $<60 \%$ \\
\hline Kurang & 2 & $<40 \%$ \\
\hline Sangat Kurang & 1 & $<20 \%$ \\
\hline
\end{tabular}

Tabel 1. Kategori Penilaian

Validitas modul dari aspek media diperoleh dari penilaian 11 indikator. Berdasarkan hasil evaluasi aspek media modul diperoleh skor rerata $51(92,7 \%)$ yang berarti modul masuk kategori "sangat baik" sebagai media pembelajaran sejarah Indonesia. Validitas modul dari aspek materi diperoleh dari penilaian 10 indikator. Berdasarkan hasil evaluasi aspek materi modul diperoleh skor rerata 46,5 (93\%) yang berarti modul masuk kategori "sangat baik" sebagai materi pembelajaran sejarah Indonesia.

\section{Implementasi dan Evaluasi Modul}

Modul akan lebih efektif dan efisien memberi pengaruh terhadap hasil pembelajaran apabila penggunaannya dibarengi dengan strategi pembelajaran yang baik (Sadiq dan Zamir, 2014:108). Penekanan pada uji coba modul lebih kepada mengetahui faktor kendala pembelajaran modul daripada mengetahui pengaruh pembelajarnya.

Uji purwarupa modul yang pertama dilakukan oleh kelompok kecil yang melibatkan empat siswa sebagai reviewernya. Pelibatan siswa tersebut berdasarkan kriteria kemampuan belajar yang berbeda yaitu tinggi, sedang, dan rendah yang diambil dari hasil nilai prestasi mid semester gasal mata pelajaran sejarah Indonesia. Pada uju ini modul sejarah lokal diimplementasikan menggunakan model pembelajaran personal dengan metode investigasi. Dasar penggunaan model ini ada pada asumsi implementasi model pembelajaran personal yang menekankan pencapaian pembelajaran tuntas (mastery goal orientation) lebih berhasil meningkatkan prestasi belajar siswa dibandingkan pembelajaran tradisional di kelas. Faktor 
lingkungan belajar yang sesuai kebutuhan siswa berperan mempengaruhi perkembangan pelatihan dan profesionalitas siswa (Clayton, Blumberg, dan Auld, 2010: 361-362). Namun dalam praktiknya penggunaan model personal ini menunjukan kelemahannya yang dapat dilihat dari perilaku siswa ketika mereka mempelajari modul tanpa bimbingan guru yaitu kesulitan memecahkan masalah. Siswa umumnya belum siap menganalisis dan mensintesiskan hubungan peristiwa lokal dengan nasional sendirian. Melihat kendala tersebut agar modul dapat dibelajarkan secara maksimal maka dilakukan kembali evaluasi terhadap model yang digunakan dengan melakukan analisis kebutuhan ulang sesuai dengan masukan dari siswa yaitu pengimplementasian model pembelajaran kelompok.

Hasil masukan dari siswa kemudian digunakan untuk implementasi modul pada kelompok yang sama. Orientasi tujuan penggunaan model kooperatif ini adalah mengkonstruksi pengetahuan siswa melalui bantuan sosial. Model ini akan berfungsi dengan baik apabila pada sebuah kelas yang memiliki jumlah populasi besar muncul kendala kurang terdistribusinya pengetahuan secara merata kepada siswa, utamanya pada pembelajaran yang membutuhkan skill atau pengetahuan khusus seperti menganalisis dan mensintesiskan sejarah nasional Indonesia dan sejarah lokal ini. Melalui pembelajaran kooperatif tiap siswa akan melahirkan penghargaan terhadap siswa lainya yang didasarkan pada kinerja yaitu penghargaan interpersonal dalam merespon usaha-usaha yang berkaitan dengan tugas kelompok (Slavin, 2015: 34-35). Proses tersebut pada akhirnya akan memberi tanggung jawab individual kepada kelompok sehingga siswa akan lebih banyak belajar dari rekan sekelompoknya melalui proses pembentukan (constructing) dan penciptaan (Daryanto dan Muljo, 2012: 229). Selama proses pembelajarannya, siswa lebih cocok dengan model ini. Hal itu dapat ditunjukan dari keberhasilan mereka mensintesiskan hubungan peristiwa lokal dengan peristiwa nasional dengan kerja sama kelompok. Melihat kemajuan hasil belajar siswa terhadap pemahaman mengaitkan antara peristiwa lokal dan nasional, maka pada ujicoba selanjutnya model pembelajaran yang ideal untuk penerapan modul di kelas besar adalah model pembelajaran kooperatif tipe group investigasi.

Uji purwarupa modul yang kedua dibelajarkan kepada 31 siswa. Uji coba skala luas ini dilakukan guna melihat kendala-kendala yang muncul di kelas dengan populasi besar sebelum diuji keefektifannya di kelas eksperimen. Model pembelajaran yang digunakan adalah model kooperatif tipe group investigasi. Pemilihan model ini didasarkan atas asumsi penciptaan pembelajaran yang bermakna bagi siswa di mana pengalaman tersebut diperoleh dari hasil 
kontruksi pengetahuan siswa yang bersumber dari penemuan mereka selama melakukan penelitian ilmiah bersama kelompok (Sharan, 2009: 145).

Sebagaimana halnya dengan prinsip manajemen pembelajaran kooperatif yang mementingkan pencapaian tujuan kelompok daripada individu dalam pencapaian tujuan akademik maka pada penggunaan model pembelajaran kooperatif tipe grup investigasi ini norma-norma penghalang yang disebabkan oleh adanya persaingan antara individu harus dihilangkang demi ketercapaian hasil pembelajaran bersama-sama (Slavin 2015: 81).

Keuntungan penerapan model ini bisa menumbuhkan kerjasama antar siswa yang ditandai dengan sikap gotong-royong, toleransi, kepekaan sosial, sikap demokratis, dan memupuk keterampilan berinteraksi sosial (Sujarwo, 2014:114). Namun kelemahan yang harus diwaspadai apabila tedapat anggota kelompok yang tidak ingin berpartisipasi dalam mengerjakan tugas karena memilih bergantung kepada siswa lain (Slavin 2015: 82).

\section{Efektivitas Modul}

Efektifitas pembelajaran modul sejarah lokal terhadap peningkatan nasionalisme siswa dapat dikatakan signifikan apabila pada diri siswa mengalami perubahan perilaku psikologis sebagai respon dari pengalaman-pengalaman mereka yang didapat selama proses belajar. Pada pengujiannya karena nasionalisme termasuk kawasan afektif atau bersifat tidak dapat dijamah secara fisik, maka untuk mengukurnya hanya diambil gambaran perubahan tingkah laku siswa yang mencerminkan perubahan akibat proses belajar. Terdapat lima aspek penilaian nasionalisme yang diukur yaitu persatuan, kebebasan, kesetaraan, kepribadian dan prestasi.

Hipotesis untuk menguji perbedaan varians:

Ho: probabilitas > 0,005 (sig/a), berarti hipotesis Ho diterima maka tidak ada perbedaan varian.

H1: probabilitas < 0,005 (sig/a), berarti hipotesis Ho ditolak maka terdapat perbedaan varians.

Hipotesis untuk menguji perbedaan rerata:

Ho: taraf signifikansi uji > 0,05 (sig/a), berarti hipotesis Ho diterima, maka tidak terdapat perbedaan rerata.

H1: taraf signifikansi uji $\leq 0,05$ (sig/a), berarti hipotesis Ho ditolak maka terdapat perbedaan rerata. 


\begin{tabular}{|c|c|c|c|c|c|c|c|}
\hline 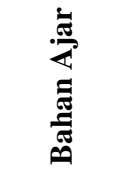 & Ex & $\stackrel{00}{20}$ & E & $\ddot{\theta}$ & 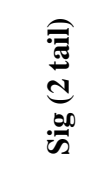 & $\mathbf{z}$ & 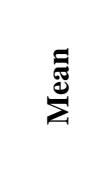 \\
\hline Modul & & 0,04 & 4,79 & 62 & 0,00 & 32 & 85,53 \\
\hline Handout & & 0,04 & 4,79 & 46,40 & 0,00 & 32 & 77,00 \\
\hline
\end{tabular}

Tabel 2: Uji Beda Nasionalisme (SPSS 20)

Berdasarkan hasil analisis tabel di atas terlihat bahwa $\mathrm{F}$ hitung untuk nasionalisme adalah 8,74 dengan probabilitas 0,004, karena probabilitas $<0,05$ maka Ho ditolak atau kedua varians benar-benar beda. Sedangkan untuk t hitung diperoleh angka sebesar 4,79 dengan probabilitas 0,000. Pada pengujian dua sisi karena probabilitas lebih kecil daripada alpha maka Ho ditolak $(0,00<0,05)$. Jika dilihat rata-rata nasionalisme kedua kelompok, skor penggunaan modul lebih tinggi daripada handout. Hal itu dapat dilihat dari penurunan derajat kebebasan/df (deegree of freedom) dari 62 menjadi 46,40 atau kegagalan mengasumsikan kesamaan varians berakibat keefektifan ukuran sampel menjadi berkurang 25,17\%. Hal mengindikasikan bahwa penggunaan modul lebih efektif $25,17 \%$ dalam peningkatan nasionalisme siswa dibandingkan dengan penggunaan handout. Handout yang dimaksud disini adalah selembaran materi pembelajaran yang berisi sejarah perjuangan Masyarakat Tengaran selama Revolusi Fisik setebal 27 halaman yang terbagi menjadi tiga bab tanpa dilengkapi gambar, kolom nasionalisme, rangkuman, dan soal latihan, sedangkan bobot materi handout setara dengan materi dalam modul yang dikembangkan.

Detail efektifitas modul dalam mempengaruhi kondisi nasionalisme siswa dapat dilihat sebagaimana rata-rata skor nasionalisme kelas eksperimen sebesar 85,53 atau meningkat sebesar 7,73 dari poin semula yang apabila dirinci per aspek: persatuan 91,78\% (sangat baik), kebebasan 85,31\% (sangat baik), persamaan 84,17\% (sangat baik), kepribadian 84,53\% (sangat baik), dan prestasi 83,13\% (sangat baik). Meskipun handout juga memiliki pengaruh terhadap peningkatan nasionalisme siswa namun tidak seefektif modul. Hal itu dapat dilihat dari kondisi nasionalisme kelas kontrol dengan skor rata-rata nasionalisme sebesar 77 atau meningkat sebesar 0,04 poin dari kondisi semula yang apabila dirinci per aspek: persatuan 87,50\% (sangat baik), kebebasan 78,12\% (baik), persamaan 77,97\% (baik), kepribadian 72,34\% (baik), dan prestasi $70,88 \%$ (baik). 
Melalui konsep mastery learning modul juga dapat meningkatkan prestasi belajar siswa. Pengukuran prestasi belajar dinilai dari aspek-aspek kemajuan yang ditunjukan siswa dalam memahami materi selama waktu tertentu, dimana dalam penelitian ini adalah materi tentang Revolusi Nasional Indonesia (Suryabrata, 2001:297).

\begin{tabular}{|c|c|c|c|c|c|c|c|}
\hline 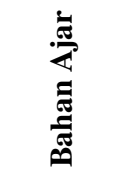 & $E$ & $\stackrel{600}{\mathrm{~B}}$ & $E$ & $\ddot{\vec{a}}$ & 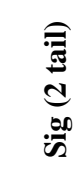 & Z & $\stackrel{\Xi}{\tilde{E}}$ \\
\hline Modul & $\sim$ & 0,02 & 3,61 & 62 & 0,01 & 32 & 80,16 \\
\hline Handout & in & 0,02 & 3,61 & 53,71 & 0,01 & 32 & 75,63 \\
\hline
\end{tabular}

Tabel 3. Uji Beda Prestasi Belajar (SPSS 20)

Berdasarkan hasil analisis di atas diperoleh t hitung sebesar 3,61 dengan probabilitas 0,02. Pada pengujian dua sisi karena probabilitas lebih kecil daripada alpha maka Ho ditolak. Jika dilihat rata-rata prestasi belajar kedua kelompok, maka skor penggunaan modul lebih tinggi daripada handout. Hal itu dapat dilihat dari penurunan derajat kebebasan/df (deegree of freedom) yaitu dari 62 menjadi 53,71 atau kegagalan mengasumsikan kesamaan varians berakibat keefektifan ukuran sampel menjadi berkurang 14,52 \%. Hal mengindikasikan bahwa efektifitas penggunaan modul 14,52\% lebih tinggi dalam meningkatkan prestasi belajar siswa dibanding penggunaan handout. Secara detailnya dapat dijelaskan dari ketuntasan belajar kedua kelompok yang mengacu pada KKM yang digunakan di SMA N 1 Tengaran yaitu perolehan nilai 75, dimana rata-rata ketuntasan ketuntasan belajar kelas eksperimen mencapai $100 \%$ sedangkan kelompok kontrol 65,62\%. Suatu kelompok dikatakan tuntas apabila syarat ketuntasan klasikal belajarnya telah mencapai $85 \%$, sehingga dapat disimpulkan bahwa dari kedua kelompok tersebut, hanya kelas eksperimen saja yang mencapai ketuntasan klasikal belajar. Itu artinya penggunaan modul sejarah lokal dalam pembelajaran sejarah Indonesia dapat meningkatkan prestasi belajar siswa.

Hasil penelitian ini turut mendukung hipotesis tentang efektifitas penggunaan modul sebagai bahan ajar mandiri yang mampu meningkatkan prestasi belajar siswa yang relevan dengan riset Padmapriya (2015) yaitu penggunaan modul pada mata pelajaran biologi (Padmapriya, 2015: 46). Begitu pula Dhamija dan Kanchan (2014) yaitu penggunaan modul pada mata pelajaran komputer (Dhamija dan Kanchan, 2014: 31). 


\section{SIMPULAN}

Analisis kebutuhan bahan ajar modul meliputi: a) ketidaklayakan bahan ajar LKS pada pembelajaran sejarah Indonesia, b) kurang tersentuhnya sumber sejarah kawasan kecamatan Tengaran untuk dijadikan sumber materi pembelajaran sejarah Indonesia, c) rendahnya motivasi belajar siswa akibat penggunaan materi pembelajaran yang monoton. Pada uji efektifitas modul diketahui bahwa produk yang dikembangkan mampu meningkatkan nasionalisme siswa dan prestasi belajar pada materi Revolusi Nasional Indonesia dibandingkan dengan penggunan bahan ajar konvensional (handout).

\section{DAFTAR PUSTAKA}

Anggoro, Dimas. 2014. "Peran Masyarakat Tengaran dalam Perjuangan Mempertahankan Kemerdekaan Republik Indonesia di Kecamatan Tengaran 1947-1949”. Skripsi. Salatiga: Progdi Pendidikan Sejarah, FKIP, Universitas Kristen Satya Wacana.

Bage, Grant. 2002. Naratif Matters: Teaching and Learning History though Story. New York: Falmer Press.

Daryanto dan Aris Dwi Cahyono. 2014. Pengembangan Perangkat Pembelajaran (Silabus, RPP, Bahan Ajar). Yogyakarta: Gava Media.

Daryanto dan Muljo Rahardjo. 2012. Model Pembelajran Inovatif. Yogyakarta: Gava Media.

Dhamija, Neelam dan Kanchan Ms. 2014. Effectiveness of Self Learning Moduleson the Achievement and Retention of Undergraduate Students in Commerce. Educationia Confab. Vol. 3, No. 2. 26-32.

Clayton, Karen, Fran Blumberg dan Daniel P. Auld. 2010 The Relationship between Motivation, Learning Strategies and Choice of Environment whether Traditional or Including An online Component. British Journal of Educational Technology. Vol. 41, No. 3. 349364.

Dick, Walter dan Carey, Lou. 1985. The Systematic Design of Instruction. 2nd ed. Glenview: Scott, Foresman \& Co. Publication.

Faiella, Filomena. 2013. Interactive White Board and Knowledge Building in Class. International Journal of Instructional Technology and Distance Learning. Vol. 10, No. 8. 37- 42 .

Fentim, Darkwa Bernard. 2014. An Investigation of Teaching andLearning Resources/Materials Used in Financial Accounting Lessons in SHS in Sunyani Municipalty. International Journal of Research in Social Sciences. Vol. 4, No. 2. 8492.

Fernández, Antoni Santisteban. 2013. Teaching the history of Catalonia: past, present and 'futures'. International Journal of Historycal Learning Teaching and Research .Vol. 11, No. 2. 34-43. 
Gestsdóttir, Margrét. 2013. The Challenges of History Education in Iceland. International Journal of Historycal Learning Teaching and Research .Vol 11, No. 2. 98-110.

Hashemi, Mansoureh dan Pourgharib, Behzad. 2013. The Effect of Visual Instructions on New Vocabularies Learning. International Journal of Basic Sciences \& Applied Research. Vol. 2, No. 6. 623-627.

Hosnan, M. 2014. Pendekatan Saintifik dan Kontekstual dalam Pembelajaran Abad 21, cet 2. Bogor: Ghalia Indonesia.

Kartodirdjo, Sartono. 1993. Pembangunan Bangsa. Yogyakarta: Aditya Media. . 2003. Multidimensi Pembangunan Bangsa Etos Nasionalisme dan Negara Kesatuan. Yogyakarta: Kanisius . 2014: Pendekatan Ilmu Sosial dalam Metodologi Sejarah. Yogyakarta: Ombak.

Kemendikbud. 2014. Sejarah Indonesia/ Buku Guru. Jakarta: Kementerian dan Kebudayaan.

Latcheva, Rossalina. 2010. Nationalism versus Patriotism, or the Floating Boarder? National Identification and Ethnic Exclusion in Postcommunist Bulgaria. Journal of Comparative Research in Anthropology and Sociology. Vol 1, No 2. 187-215.

Larawan, Lucell. 2013. Acceptability of Teacher Made Modules in Production Management. International Journal of Managerial Studies and Research (IJMSR). Vol. 1, Issue 2. $10-22$.

Macarandang, Mercedes A. 2009. Evaluation of A Proposed Set of Modules in Principles and Methods of Teaching. E International Scientific Research Journal. ISSN: 20941749 Vol 1, Issue 1. 1-24.

Martin, Florence, dkk., 2013. Development of an Interactive Multimedia Instructional Module. The Journal of Applied Instructional Design. Vol 3, Issue 3. 5-17.

Naval, D.J., 2014. Development and Validation of Tenth Grade Physics Modules Based on Selected Least Mastered Competencies. International Journal of Education and Research. Vol. 2, No. 12. 145152.

Peraturan Pemerintah Republik Indonesia Nomor 19 Tahun 2005 tentang Standar Nasional Pendidikan. Diunduh dari www.unm.ac.id/files/.../pp-19tah un2005-ttg-snp.pd. Pada 14/07 /2015.

Padmapriya P.V. 2015. Effectiveness of Self Learning Modules Achievement in Biologi Among Secondary School Students. International Journal of Education and Psycological Research. Vol. 4, Issue 2. 44-16.

Pranoto, Suhartono. W. 2010. Teori dan Metodologi Sejarah. Yogyakarta: Graha Ilmu.

Pribadi, Benny A. 2014. Desain dan Pengembangan Program Pelatihan Berbasis Kompetensi Implementasi Model ADDIE. Jakarta: Kencana. 
Rocher, François. 2002. The Evolving Parameters of Quebec Nationalism. International Journal on Multicultural Societis, Vol 4, No. 1. 1-21.

Rustam. 2014. Model-model Pembelajaran Mengembangkan Profesionalisme Guru, edisi kedua. Jakarta: Raja Grafindo Persada.

Sadiq, Sadia dan Zamir, Shazia. 2014. Effectivenes of Modular Approach in Teaching at Universty Level. Journal of Education and Practice. Vol. 5, No. 17. 103-109.

Sharan, Shlomo. 2009. Handbook of Cooperatif Learning Inovasi Pengajaran dan Pembelajaran untuk Memacu Keberhasilan Siswa di Kelas. Edisi terjemahan oleh Sigit Prawoto. Yogyakarta: Imperium.

Slavin, Robert E. 2015. Cooperative Learning Teori, Riset, dan Praktik. Edisi terjemahan oleh Narulita Yusron. Bandung: Nusa Media.

Schunk, Dale H. 2012. Learning Theories An Educational Perspective (Teori teori Pembelajran: Perspektif Pendidikan) Edisi Keenam. Edisi terjemahan oleh Eva Hamdiah dan Rahmat Fajar. Yogyakarta: Pustaka Pelajar.

Stokes, Suzanne. 2002. Visual Literacy in Teaching and Learning A Literature Perspective. Electronic Journal for the Integration of Technology in Education. Vol. 1, No. 1. 1019.

Sugeng Priyadi. 2014. Sejarah Lokal,Konsep, Metode, dan Tantangan.Yoedgyakarta: Ombak.

Sujarwo. 2014. Model-model Pembelajaran Suatu Strategi Mengajar. Yogyakarta: Venus Gold Press.

Sugiyono. 2013. Metode Penelitian Pendidikan Pendekatan Kuantitatif, Kualitatif, dan R\&D. Bandung: Alfabeta.

Sukamadinata, Nana Syaodih. 2007. Metode Penelitian Pendidikan. Bandung: Remaja Rosdakarya.

Suryabrata, Sumadi. 2001. Psikologi Pendidikan. Jakarta: Raja GrafindoPersada.

Tanner, M. Julee. 2014. Digital vs. Print: Reading Comprehension and theFuture of the Book. iSchool Student Research Journal. Vol. 4, Issue 2. 1-12.

Tsyrlina, Tatyana, Spady dan Michael Lovorn. 2015. A Curriculum of Ideology: Use and Abuse of Modern History Education in Russia and the United States.International Dialogues on Education. Vol.2, No. 2. 161-171.

Undang-undang Republik Indonesia Nomor 20 Tahun 2003 tentang Sistem Pendidikan Nasional. Diunduh dari luk.staff.ugm.ac.id/atur/UU202003Sisnas.pdf. pada 14/ $07 / 2015$.

Voronkova, Anastasia dan Mansour Dina.2015. Introduction: Nationalism and Belonging. Studies in Ethnicity and Nationalism. Vol. 15, No. 1, 1-3. 